The University of Southern Mississippi

The Aquila Digital Community

Faculty Publications

$1-1-2005$

\title{
Arrival Timing and Seasonal Reproductive Performance in a Long- Distance Migratory Landbird
}

Robert J. Smith

University of Southern Mississippi, smithr9@scranton.edu

Frank R. Moore

University of Southern Mississippi, Frank.Moore@usm.edu

Follow this and additional works at: https://aquila.usm.edu/fac_pubs

Part of the Biology Commons

\section{Recommended Citation}

Smith, R. J., Moore, F. R. (2005). Arrival Timing and Seasonal Reproductive Performance in a LongDistance Migratory Landbird. Behavioral Ecology and Sociobiology, 57(3), 231-239.

Available at: https://aquila.usm.edu/fac_pubs/8588

This Article is brought to you for free and open access by The Aquila Digital Community. It has been accepted for inclusion in Faculty Publications by an authorized administrator of The Aquila Digital Community. For more information, please contact Joshua.Cromwell@usm.edu. 


\title{
Original Article
}

\section{Arrival timing and seasonal reproductive performance in a long- distance migratory landbird}

\author{
Robert J. Smith ${ }^{1,2}{ }^{\text {and Frank R. Moore }}{ }^{1}$ \\ (1) Department of Biological Sciences, University of Southern Mississippi, Hattiesburg, MS 39406-5018, USA \\ (2) Present address: Department of Biology, University of Scranton, Scranton, Pennsylvania 18510, USA \\ $\triangle$ Robert J. Smith \\ Email: Smithr9@Scranton.edu
}

Received: 15 March 2004 Revised: 7 September 2004 Accepted: 29 September 2004 Published online: 21 October 2004

\begin{abstract}
The date when a landbird migrant arrives on its breeding grounds may have reproductive consequences. Generally, early arriving individuals begin breeding earlier and consequently experience greater seasonal reproductive performance. Here, we describe relationships between arrival timing and seasonal reproductive performance in the American redstart (Setophaga ruticilla), a long-distance passerine migrant, arriving at northerly breeding grounds in Michigan's eastern Upper Peninsula. Evidence suggests that both males and females benefited from early arrival at the breeding grounds. Early males appeared to settle on higher quality territories and hatched nestlings sooner than later arrivals. Early females began their clutches early, produced heavier nestlings and possibly laid more eggs than later arrivals. Larger clutches and heavier offspring increase the likelihood of offspring recruiting into the breeding population. The findings of this study point to fitness consequences arising from when a bird arrives at its breeding grounds. These results also have implications for understanding how events occurring during spring migration influence reproductive performance as migratory delays likely influence arrival timing.
\end{abstract}

Keywords Arrival timing - Landbird migrant - Migration-breeding linkage - Setophaga ruticilla

Communicated by: W. Wiltschko

\section{Introduction}

The date when a landbird migrant arrives on its breeding grounds may have important reproductive consequences. For instance, males that arrive early increase the likelihood of acquiring a mate (Møller 1994b; Lozano et al. 1996), not to mention a mate of high quality (Arvidsson and Neergaard 1991; Møller 1994a; Rowe et al. 1994; Lozano et al. 1996). Male arrival timing has also been linked to the likelihood of extra-pair mating success (Langefors et al. 1998) or chance of polygyny (Hasselquist 1998 ). Further, many bird species require breeding territories to rear offspring, and evidence indicates these territories vary significantly in quality (Brown 1969; Wolfenbarger 1999). Variability in territory quality may relate to several factors, including food availability, presence of suitable nesting sites, and predator exposure. Among migratory species, early arrival may allow priority of access to the highest quality territories (Bensch and Hasselquist 1991; Aebischer et al. 1996; Lozano et al. 1996). This presumptive advantage is often cited as an explanation for the territorial sex preceding the non-territorial sex during migration and on arrival (Francis and Cooke 1986; Stewart et al. 2002)

Arrival timing may also influence female reproductive performance. An early female has more latitude to choose a high-quality male or territory, as fewer males will be paired relative to later in the arrival period (Bensch and Hasselquist 1992). Early arrival also provides time to renest should the first attempt fail, or to fledge a second brood. Evidence shows that early females begin breeding sooner than later arrivals (Bensch and Hasselquist 1992; Cristol 1995). Early breeders experience higher reproductive success (Perrins 1970; Rowe et al. 1994), often through increases in clutch size and offspring size (Martin 1987; Perrins and McCleery 1989; Smith and Bruun 1998). Relationships between arrival date, territory quality and seasonal reproductive performance highlight the importance of settlement tactics for both male and female migratory birds that hold breeding territories (Aebischer et al. 1996).

This study examined the relationship between arrival timing and seasonal reproductive performance in a long-distance landbird 
migrant, the American redstart (Setophaga ruticilla), arriving at northerly breeding grounds in Michigan's eastern Upper Peninsula. Specifically, we evaluated the influence of arrival day on: (1) territory quality, as reflected by territory vegetation, (2) timing of breeding, and (3) seasonal reproductive performance. We tested the following predictions:

1. Given redstarts' preference for young, second-growth forest with abundant shrubs (Sherry and Holmes 1997), we expected early arriving males to settle on territories encompassing more second-growth vegetation than later arrivals. Variation in forest age allowed evaluation of this prediction. The study area was characterized by a gradient of differentially aged patches ranging from $<20$ years to $>75$ years since clearing. The youngest areas contained dense stands of young balsam fir (Abies balsamea), with no canopy, whereas the oldest patches were dominated by older northern white cedar (Thuja occidentalis), and contained little to no shrubby vegetation.

2. Breeding date is positively affected by arrival date. This prediction reflects the increased probability of offspring successfully entering the breeding population if fledged early (Perrins and McCleery 1989; Rowe et al. 1994).

3. Arrival timing influences reproductive performance; early arriving individuals produce larger clutches with heavier eggs and nestlings than later arrivals. Egg and nestling size relate positively to recruitment probability (Magrath 1991, 1992).

\section{Methods}

This work was conducted during the spring migratory and breeding periods at a 5-ha site located on the shoreline of northern Lake Huron in Michigan 's eastern Upper Peninsula $\left(46^{\circ} 2^{\prime} \mathrm{N}, 84^{\circ} 35^{\prime \prime} \mathrm{W}\right)$. Forest vegetation was a mixture of conifers, including balsam fir, northern white cedar, white spruce (Picea glauca), white pine (Pinus strobus), and red pine $(P$, resinosa), and deciduous species, including paper birch (Betula papyrifera) quaking aspen (Populus tremuloides), and balsam poplar $(P$, balsamifera). Relative densities of each species were as follows: northern white cedar $61 \%$, balsam fir $10 \%$, quaking aspen $7 \%$, white spruce $5 \%$, paper birch $2 \%$, white pine $1 \%$, red pine $<1 \%$, and balsam poplar $<1 \%$ (Smith and Moore, unpublished). Vegetation composition within the study site was representative of the lowland coniferous forests common in shoreline habitats throughout eastern Upper Peninsula of Michigan (Smith and Moore, unpublished data).

American redstarts were trapped daily using mist-nets $(12 \times 2.6 \mathrm{~m}, 30 \mathrm{~mm}$ mesh) from 7 May through 6 June 1997 , 4 May through 28 June 1998, 30 April through 23 July 1999, 27 April through 29 July 2000 and 27 April through 26 July 2001. We used a combination of passive and active netting to maximize the likelihood of capturing birds on the day they arrived. After an initial pilot season (1997), we increased the number of nets and extended the netting period through the end of July to better understand the biology of redstarts breeding in the eastern Upper Peninsula. Except for 1997, in which we used only 10 nets, we ran 25-30 permanently positioned mist-nets to sample the avian fauna. During the arrival period this netting was supplemented by intensively searching the area, capturing new arrivals by placing temporary nets in the new arrival's territory and broadcasting song-chip playbacks. Analyses were restricted to first captures of birds before 12 June to ensure capture data accurately reflected arrival day.

Nets were opened shortly before sunrise, remaining open through early afternoon. Nets were reopened in early evening and closed at dusk. Nets were closed if the temperature dropped below $3^{\circ} \mathrm{C}$, or in the event of high wind or rain. Standard measurements taken from each bird included body mass, tarsus length and unflattened wing chord. Visible, subcutaneous fat deposits were quantified using a 6-point ordinal scale (Helms and Drury 1960). This commonly used procedure (e.g., Woodrey and Moore 1997) provides a repeatable method of indexing fat stores as long as comparisons are made within species (Krementz and Pendleton 1990). All measures were performed by trained individuals periodically tested by R.J.S. to ensure validity and repeatability of measures. Each bird was aged and sexed according to characteristics outlined in Pyle (1997), fitted with a USFWS aluminum band and a unique combination of up to 3 colorbands (two colorbands on one leg, one color plus the aluminum band on the other). All recaptures were measured without reference to previous records.

\section{Nests}

We searched for nests daily. After finding a nest, the color-band combination of each adult was verified and the nest monitored to determine clutch initiation date, clutch size, egg mass and nestling mass at day 5 (hatch day $=$ day 0 ). If a nest was found with a partially completed clutch, daily monitoring continued to establish final clutch size. Clutch initiation day was then estimated by backdating 1 day for each egg. American redstarts typically lay one egg a day (Sherry and Holmes 1997 ). Nests were only included in analyses if we were confident of clutch initiation date. Where necessary, we estimated hatch and fledge dates based on averages calculated from nests for which these dates were known. Egg and nestling mass were determined using an electronic balance and nestlings fitted with aluminum USFWS bands at day 5 or day 6 . We calculated mean egg and nestling mass for each clutch; these averages are used in subsequent analyses.

\section{Territory vegetation}


We estimated vegetation composition after nestlings fledged using a modification of methodology proposed by James and Shugart $(\underline{1970})$. We used two vegetation sampling points to characterize each territory. Due to the size of redstart territories, using more than two points would often have resulted in sampling the bordering male's territory. We located one point at the nest and one at a random direction and distance from the nest, yet remaining within the attending male's territory. Territory boundaries were delineated by noting locations of singing males and aggressive interactions with other males. We included for analysis only those males for which we were confident of territory boundaries.

At each sampling point, we recorded tree species [ $>7.4 \mathrm{~cm}$ diameter at breast height $(\mathrm{dbh})]$, and number within an $11.2-\mathrm{m}$ radius circle. Further, we estimated dbh, placing each stem into 1 of 6 size categories. Demarcation diameters for stem sizes were $<7.4 \mathrm{~cm}$ : shrub; 7.5-15.4 cm: size class A; 15.5-22.5 cm: size class B; 22.6-37.5 cm: size class C; $37.6-52.5 \mathrm{~cm}$ : size class D; and 52.6-67.5 cm: size class E. We estimated shrub density by walking in each cardinal direction for $11.2 \mathrm{~m}$, counting the number of stems intersecting the sampling individual's outstretched arms. Ground and canopy cover were estimated at 20 locations within a vegetation circle by looking through an ocular tube with crosshairs and noting whether the crosshairs intersected green vegetation or not. Cover readings were taken in either a north-south or east-west direction. Finally, we estimated the height of the five tallest trees within a sampling circle using a clinometer and range finder, converting distance and angle readings to tree height using trigonometric equations.

Because we predicted that vegetation of an earlier successional stage would be preferred by male redstarts, we evaluated relationships between male arrival day and variables associated with vegetation age within a male's territory. These included basal area of vegetation by size class and density of shrubs. Basal area represents the cross-sectional area of each tree at breast height and provides an indication of stand density (Brower et al. 1990). At our site young-aged, early successional forest patches were characterized by higher shrub densities and greater basal area of smaller trees than older-aged forests.

\section{Data analysis}

Data describing redstart arrival in 1997 were excluded because of small sample sizes. We performed all analyses using SPSS 9.0 (SPSS 1999) and SYSTAT 9.0 (Wilkinson 1998). Distributions of relevant variables were examined for departures from normality and the proper non-parametric statistics used when transformations did not bring data into compliance with parametric testing assumptions (Zar 1996). Arrival dates were compared using general linear models (GLM) on ranks, Kruskal-Wallis Analysis of Variance, and Mann-Whitney tests (Zar 1996). Where necessary, we used Dunn's test to make nonparametric multiple comparisons. We made comparisons of nesting dates by male age using GLM, and examined the various relationships between arrival timing, territory vegetation and reproductive performance using correlational analyses. To control for familywise error we adjusted critical $P$-values using the Sequential Bonferroni procedure (Hochberg 1988 ). We have included both the calculated $P$-value and the Bonferroni $\alpha_{1}$ value where necessary. We considered results as statistically significant when the calculated $P$-value was less than or equal to the adjusted significance level $\left(\alpha_{1}\right)$. Finally, as we made a priori predictions, many statistical tests are one-tailed. These are indicated as necessary.

\section{Results}

Birds arrived over a 5-week period, with the earliest male arriving on 6 May in 1999 and the earliest female arriving on 7 May in 2001 (Fig. 1). Overall, the arrival period was more compressed for females than males, with the first $75 \%$ of males arriving over a 23 -day period and the first $75 \%$ of females arriving over a 16-day period. Pooled across years, median arrival day for breeding males was 24 May (Julian Day 144) and for females 26 May (Julian Day 146). This two-day difference was not significant (

$\left.\chi^{2}=1.007, d f=1, n=431, P=0.366\right)$. 

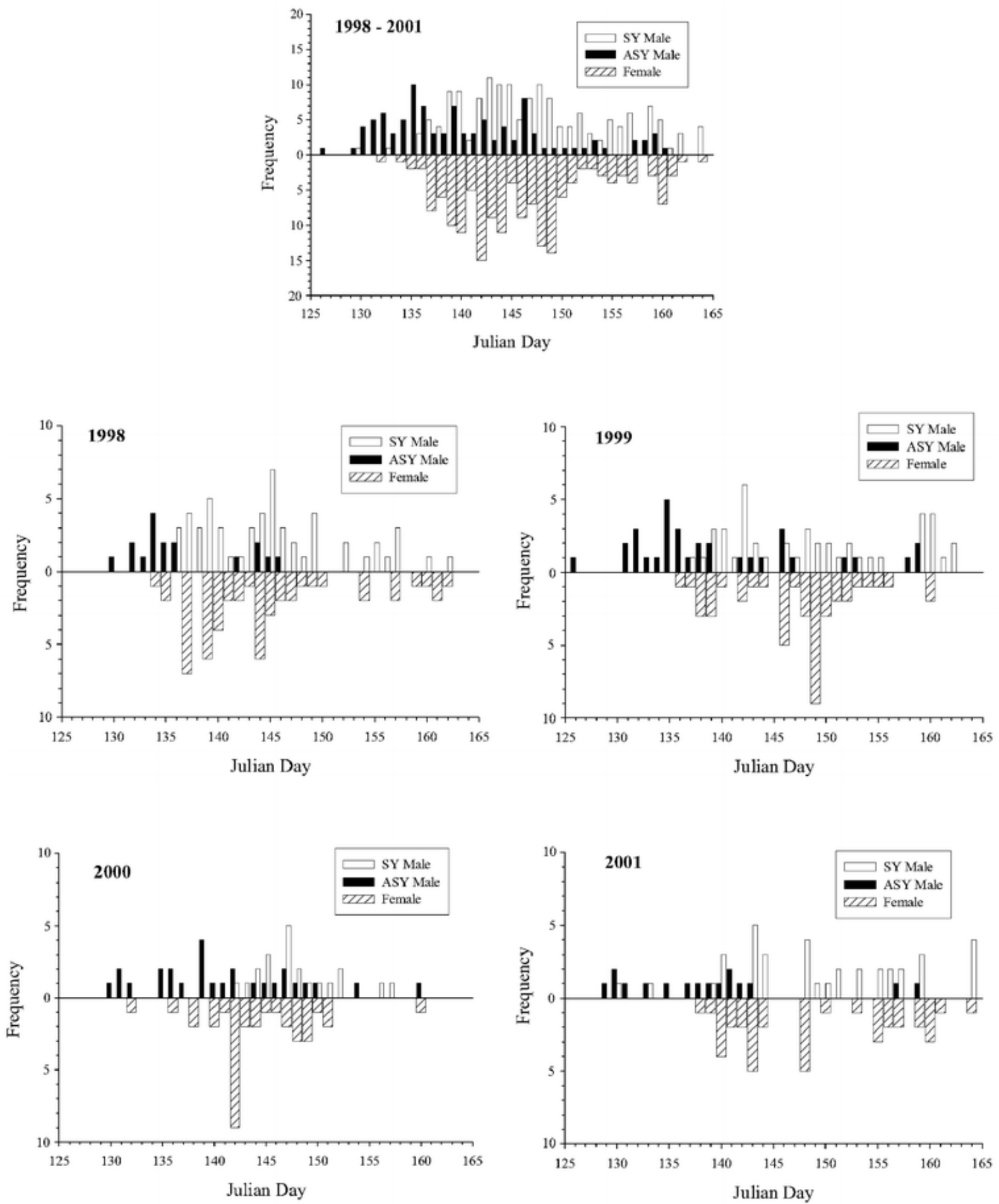

Fig. 1 Arrival sequence of breeding American redstarts (Setophaga ruticilla) as a function of sex and male age, Pontchartrain Shores, Michigan, 1998-2001

There was a significant effect of year $\left(F_{4,421}=4.628, P=0.001\right)$ on arrival day, although no effect of sex $\left(F_{1,421}=0.898, P=0.344\right)$ nor a sex-by-year interaction $\left(F_{4,421}=0.695, P=0.596\right)$. Birds arrived in 1998 earlier than in other years (Fig. 2$)$. Because redstart males are readily aged by plumage as second year (SY), birds hatched the previous year and in their first breeding season, and after second year (ASY), birds in at least their second breeding season (Pyle 1997), we were able to assess yearly variation in arrival timing by male age. This yearly variation was not significant in ASY males $\left(\chi^{2}=4.685, d f=3, P=0.196\right)$, although it was 
significant in both SY males ( $\chi^{2}=10.137, d f=3, P=0.017$ ) and females ( $\chi^{2}=12.301, d f=3, P=0.006$ ). Second-year male arrival did not differ between 1999 and 2000 (Dunn's $P>0.05$ ), but differed in all other year-to-year comparisons (all Dunn's $P<0.005$ ). Female arrival did not differ between 1998 and 2000 (Dunn's $P>0.05$ ), but differed in all other year-to-year comparisons (all Dunn's $P<0.001)$.
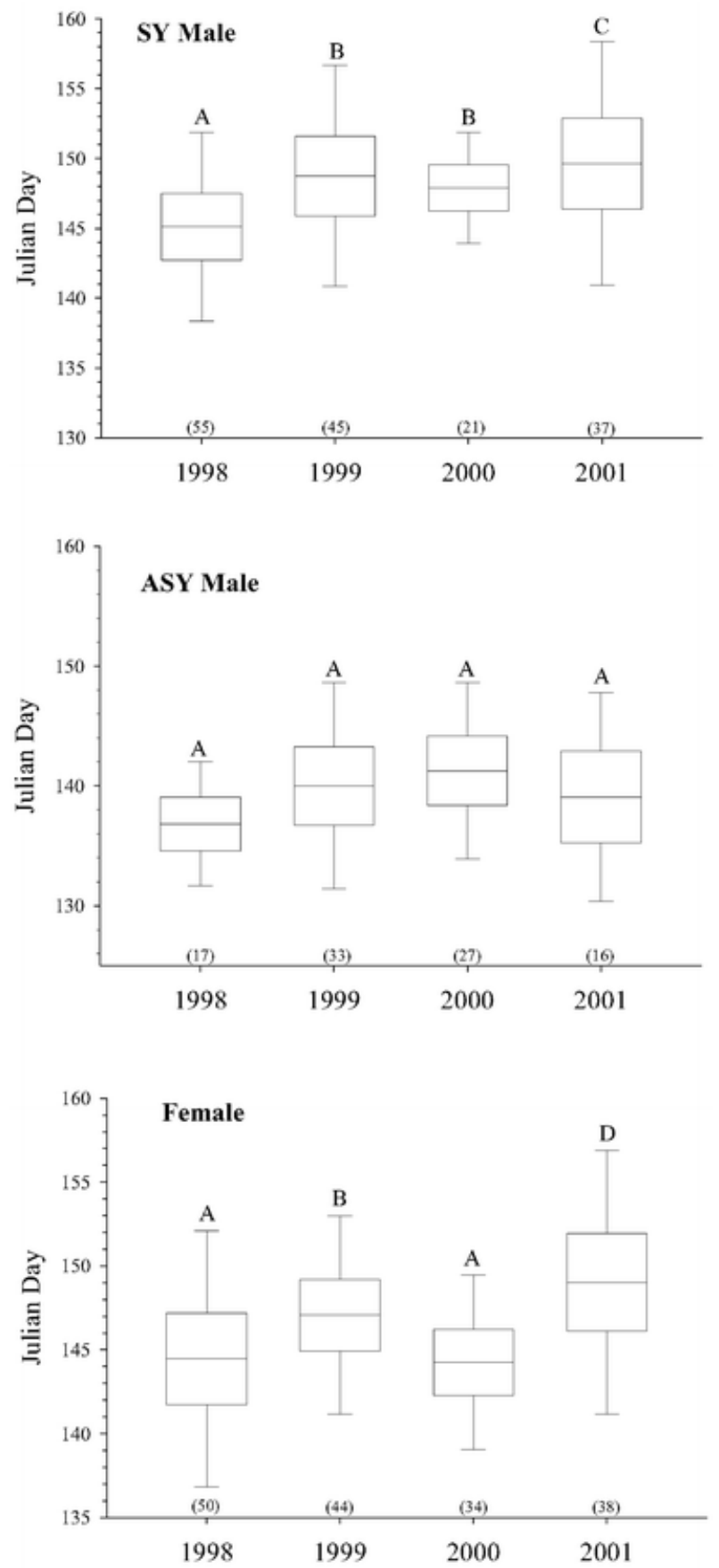

Fig. 2 Yearly variation in arrival date for American redstarts, Pontchartrain Shores, 1998-2001. Within each graph, different letters indicate significant differences between years. Lines indicate mean, boxes $\pm 1 \mathrm{SE}$, and whiskers $\pm 1 \mathrm{SD}$

There were clear age differences in the arrival of males $\left(F_{2,416}=40.068, P<0.001\right)$. In all years, older males preceded younger males, with differences in median arrival day ranging from a low of seven days in 2000 to a high of 11 days in 1999 (Table 1 ). 
Table 1 Arrival dates by sex and male age for breeding American restarts (Setophaga ruticilla) at Pontchartrain Shores, Michigan. Data from 1997 omitted because small sample sizes do not accurately reflect arrival. Male age comparison were made using Mann-Whitney tests

\begin{tabular}{|c|c|c|c|c|c|c|c|c|c|}
\hline & Mean & \begin{tabular}{|l|l|} 
Median \\
\end{tabular} & SE & $\mathrm{CV}$ & $\operatorname{Min}$ & Max & \begin{tabular}{|l|}
$n$ \\
\end{tabular} & $\overline{Z Z}$ & $\bar{P}$ \\
\hline \multicolumn{10}{|l|}{ 1998-2001 } \\
\hline SY male & \begin{tabular}{|l|}
147.58 \\
\end{tabular} & 147 & 0.60 & 5.08 & 130 & 164 & 158 & & \\
\hline ASY male & 140.42 & 139 & 0.81 & 5.77 [ & 126 & 160 & 101 & \begin{tabular}{|l|}
-6.865 \\
\end{tabular} & $<0.001$ \\
\hline Female & 146.19 & 146 & 0.53 & 4.74 [ & 132 & 164 & 171 & & \\
\hline \multicolumn{10}{|l|}{1998} \\
\hline SY male & 145.11 & 145 & 0.91 & \begin{tabular}{|l|l|}
4.67 \\
\end{tabular} & 136 & 162 & 55 & & \\
\hline ASY male & 136.82 & 135 & 1.26 & 3.79 & 130 & 146 & 17 & 4.370 & $<0.001$ \\
\hline Female & 144.46 & 143.5 & 1.08 & 5.29 & 134 & 162 & 50 & & \\
\hline \multicolumn{10}{|l|}{1999} \\
\hline SY male & 148.76 & 148 & 1.18 & 5.32 & 137 & 162 & 45 & & \\
\hline ASY male & 140.00 & 137 & \begin{tabular}{|l|}
1.50 \\
\end{tabular} & 6.15 & 126 & 159 & 33 & 4.471 & 0.00 \\
\hline Female & 147.07 & 148.5 & 0.89 & 4.02 & 136 & 160 & 44 & & \\
\hline \multicolumn{10}{|l|}{2000} \\
\hline SY male & 147.91 & 147 & 0.87 & 2.69 & 142 & 157 & 21 & & \\
\hline ASY male & 141.14 & 140 & 1.41 & 5.20 & 130 & 160 & 27 & -3.438 & 0.001 \\
\hline Female & 144.27 & 143 & 0.89 & 3.60 & 132 & 160 & 34 & & \\
\hline \multicolumn{10}{|l|}{2001} \\
\hline SY male & 149.65 & 149 & 1.43 & 5.83 & \begin{tabular}{|l|}
130 \\
\end{tabular} & 164 & 37 & & \\
\hline \begin{tabular}{|l|} 
ASY male \\
\end{tabular} & 139.06 & 138.5 & 2.18 & 6.27 & 129 & 159 & 16 & \begin{tabular}{|l|}
-3.737 \\
\end{tabular} & $<0.001$ \\
\hline Female & 149.03 & 148 & 1.28 & 5.28 & 138 & 164 & 38 & & \\
\hline
\end{tabular}

\section{Arrival timing and territory vegetation}

Relationships between basal area of vegetation size class, one of our measures of territory quality, and male arrival date were not significant after Sequential Bonferroni correction (Table 2). Examining these same relationships within age class revealed four correlations in ASY males that approached significance and one that was significant after Sequential Bonferroni correction (Table 2). There were no relationships between basal area by size class and SY male arrival day (Table 2). Shrub density within a male's territory was related to arrival day $\left(r_{\mathrm{s}}=0.451, n=55\right.$, one-tailed $\left.P<0.001\right)$. Stratifying by age class revealed that shrub density was negatively related to arrival day in both SY males $\left(r_{\mathrm{s}}=0.322, n=30\right.$, one-tailed $\left.P=0.041\right)$ and ASY males $\left(r_{\mathrm{s}}=\right.$ $0.368, n=30$, one-tailed $P=0.020)$.

Table 2 Correlations between male arrival day and basal area by size class of trees within that male's territory. The adjusted $P$-value was calculated using the Sequential Bonferonni procedure of Hochberg (1988)

\begin{tabular}{|c|c|c|c|c|c|}
\hline Basal Area & Spearman's $r$ & $n$ & Calculated $\boldsymbol{P}$ (one-tailed) & Bonferonni $\alpha_{1}$ & Significant after correction \\
\hline \multicolumn{6}{|l|}{ Ages pooled } \\
\hline Size class A & 0.013 & & 0.462 & 0.050 & No \\
\hline Size class B & -0.086 & & 0.267 & 0.025 & No \\
\hline Size class C & -0.097 & & 0.240 & 0.017 & No \\
\hline Size class D & 0.140 & 55 & 0.154 & 0.013 & No \\
\hline Size class E & 0.273 & & 0.022 & 0.010 & No \\
\hline \multicolumn{6}{|l|}{ ASY males } \\
\hline Size class A & -0.400 & 29 & 0.016 & 0.013 & No \\
\hline Size class B & -0.431 & 29 & 0.010 & 0.010 & Yes \\
\hline Size class C & -0.097 & 29 & 0.308 & 0.050 & No \\
\hline Size class D & 0.339 & 29 & 0.036 & 0.017 & No \\
\hline Size class E & 0.325 & & 0.043 & 0.025 & No \\
\hline \multicolumn{6}{|l|}{ SY Males } \\
\hline Size class A & -0.001 & 26 & 0.499 & 0.05 & No \\
\hline Size class B & -0.026 & 26 & 0.449 & 0.017 & No \\
\hline Size class $\mathrm{C}$ & -0.016 & 26 & 0.469 & 0.025 & No \\
\hline Size class D & -0.063 & 26 & 0.379 & 0.013 & No \\
\hline Size class E & 0.150 & 26 & 0.232 & 0.010 & No \\
\hline
\end{tabular}




\section{Arrival timing and reproduction}

The number of eggs a female produced was inversely related to when she initiated her clutch $\left(r_{\mathrm{P}}=0.524, n=39, P=0.001\right)$. There were not, however, relationships between average egg mass $\left(r_{\mathrm{P}}=0.132, n=33, P=0.463\right)$, nor average nestling mass at day 5 $\left(r_{\mathrm{P}}=0.088, n=24, P=0.681\right)$ and clutch initiation day.

Clutch initiation date was related to female arrival day $\left(r_{\mathrm{p}}=0.585, n=40\right.$, one-tailed $P<0.001 ; \alpha \alpha_{1}=0.017$; Fig. 3 ). Because both hatch day $\left(r_{\mathrm{P}}=0.988, n=39, P<0.001\right)$ and fledge day $\left(r_{\mathrm{P}}=0.981, n=34, P=0.001\right)$ were related to clutch initiation day, we ran partial correlations to control for clutch initiation day. There was a relationship between female hatch day and arrival day (Partial $r_{\mathrm{P}=}=0.504, n=36$, one-tailed $P<0.001, \alpha_{1}=0.025$ ) and fledge day and arrival day (Partial $r_{\mathrm{P}}=0.483, n=31$, one-tailed $P=0.002$, $\left.\alpha_{1}=0.05\right)$.

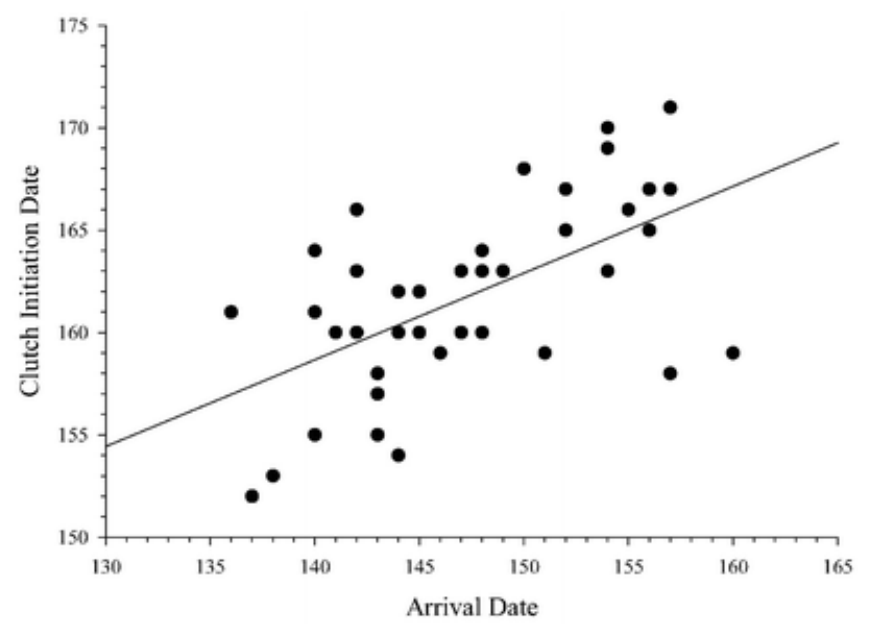

Fig. 3 Relationship between female first capture date and clutch initiation date, Pontchartrain Shores Michigan, 1998-2001. Dates are Julian

Because there were significant differences by male age in clutch initiation day $\left(F_{1,37}=14.766, P<0.001\right)$, hatch day $\left(F_{1,37}=12.030, P=0.001\right)$ and fledge day $\left(F_{1,37}=13.822, P=0.001\right)$, we controlled for male age by running correlations within age class. Female clutch initiation day was unrelated to when the male she was paired with arrived (ASY $r_{\mathrm{P}=}-0.038, n=17$, one-tailed $P=0.442, \alpha_{1}=0.05$; SY $r_{\mathrm{P}}=0.021, n=21$, one-tailed $\left.P=0.464, \alpha_{1}=0.05\right)$. After controlling for clutch initiation day, hatch day was related to male arrival day in both age classes (ASY: Partial $r_{\mathrm{P}}=0.474, n=14$, one-tailed $P=0.016, \alpha_{1}=0.017$; SY Partial $r_{\mathrm{P}}=0.391, n=18$, one-tailed $\left.P=0.023, \alpha_{1}=0.025\right)$. There was no relationship between fledge day and arrival day in ASY males (Partial $r_{\mathrm{P}}=0.448, n=8$, one-tailed $P=0.049, \alpha_{1}=0.025$ ) though there was in SY males (Partial $r_{\mathrm{P}}=0.438, n=18$, one-tailed $\left.P=0.014, \alpha_{1}=0.016\right)$.

Average nestling mass at day 5 correlated with female arrival day $\left(r_{\mathrm{s}}=-0.446, n=34\right.$, one-tailed $\left.P=0.004, \alpha_{1}=0.017\right)$. Further, the relationship between number of eggs per clutch and arrival day approached significance $\left(r_{\mathrm{s}}=0.357, n=35\right.$, one-tailed $P=0.040$, $\left.\alpha_{1}=0.025\right)$. We found no relationship between egg mass and female arrival day $\left(r_{\mathrm{s}}=0.004, n=41\right.$, one-tailed $P=0.490$, $\left.\alpha_{1}=0.05\right)$. Average nestling mass at day $5\left(r_{\mathrm{s}}=0.053, n=21\right.$, one-tailed $\left.P=0.410, \alpha_{1}=0.05\right)$, number of eggs per clutch $\left(r_{\mathrm{s}}=\right.$ $0.200, n=20$, one-tailed $\left.P=0.199, \alpha_{1}=0.025\right)$ and average egg mass $\left(r_{\mathrm{s}}=0.200, n=29\right.$, one-tailed $\left.P=0.119, \alpha_{1}=0.017\right)$ were all unrelated to when a male arrived.

\section{Discussion}

Most of the individuals that bred at our site arrived and settled during a 2- to 3-week period, which is typical for a long-distance 
migrant with a restricted breeding schedule (Widmer and Biebach 2001; but see Møller 1994b). Birds began breeding activities almost immediately after arrival; males were territorial within hours and females typically paired by the end of their second day (R. Smith, personal observation; Sherry and Holmes 1997). Males did not differ from females in the date of arrival at our site, which differs from what is typically found in many passerines (Nolan 1978; Møller 1994b). The lack of a sex effect on arrival day might be a consequence of early season male movement acting to skew arrival estimates. Anecdotal evidence suggests male redstarts may be highly mobile for a short period of time immediately following arrival at the breeding grounds (R. Smith personal observation; T. Sherry, personal communication). It is our impression that male movement during this period is a consequence of birds exploring potential territories (see also Hasselquist 1994).

There was year-to-year variation in redstart arrival. Part of this variation appears attributable to environmental conditions, as shown by the early arrival in 1998. The year 1998 was characterized by warm temperatures, advanced leaf development in aspen and more food than in other years of this work (Smith 2003). Nolan (1978) documented annual variation in arrival of prairie warblers (Dendroica discolor) at breeding grounds, attributing some of this variation to environmental conditions. More recently, Forchhammer et al. (2002) found a strong influence of regional climate effects associated with the North Atlantic Oscillation on springtime arrival of short-distance migrants (thought to track closely the onset of spring; Hagan et al. 1991) with less of an effect on arrival of long-distance migrants (endogenously controlled onset of migration; Berthold 1996). Lozano et al. (1996) also showed yearly variation in arrival timing for male redstarts at breeding grounds in New Brunswick, Canada, but made no attempt to explain this variation.

\section{Age effects}

Older birds typically arrive earlier at the breeding grounds than younger birds (Nolan $\underline{1978}$; Cristol 1995), which was the case for male redstarts arriving at our site. As a consequence, it may be that the observed relationships between arrival day and reproductive performance in redstarts were an outcome of age rather than arrival timing. The effect of age on reproductive performance in birds is well documented, with older, more experienced individuals of both sexes typically enjoying increased fitness relative to younger, inexperienced birds (Saether 1990). Improvements in breeding performance associated with age are thought primarily a consequence of enhanced competence associated with breeding experience, mate experience, social status and foraging ability (see Pärt 2001). We did not control for female age in this study and suggest that female age may have played a role in the observed relationships between female arrival date and reproductive performance. Birds may have experienced better reproductive performance because of experience or some other age-related reason instead of arrival day per se.

Our results suggest that, even though age played a role in reproductive performance, arrival timing remained a factor. Relationships between arrival day and territory vegetation, along with arrival day and reproductive performance, were present after controlling for male age. Further, evidence that arrival timing influenced reproductive performance has been found by other researchers. Cristol (1995) experimentally manipulated arrival day in female red-winged blackbirds (Agelaius phoeniceus), showing that arrival timing influenced laying date. Landmann and Kollinsky (1995) found mating success to vary significantly with arrival timing within age class in male black redstarts (Phoenicurus ochruros) while Lozano et al. (1996) concluded that reproductive success in male American redstarts was independently affected by both age and arrival day.

Differential arrival by age might be a result of different migration speeds (e.g., Ellegren 1990$)$, reflecting morphological differences (Yong and Moore 1994) or en route factors such as social dominance (Moore et al. 2003). There were clear differences in morphology by age in male redstarts arriving in northern Michigan. For instance, ASY male wing length averaged $3.5 \mathrm{~mm}$ longer than SY males (Smith and Moore, unpublished), which may have resulted in increased flight efficiency for older birds (Yong and Moore 1994). If older males were more efficient flyers than younger males, they may have been able to increase migration speed by reducing time spent on stopover relative to time spent en route (sensu Alerstam and Lindström 1990 ). Further, subordinate migrants may have been forced into suboptimal habitats, depressing fat deposition rate and the overall migration speed (Yong et al. 1998). Woodrey (1995) found evidence for age-related dominance in fall migrating redstarts, suggesting that young birds were displaced to less preferred habitats and as a result, suffering increased predator exposure. Social dominance by age and sex in redstarts has also been observed on the wintering (Parrish and Sherry 1994; Marra et al. 1998) and breeding grounds (see Sherry and Holmes 1997).

Differential arrival at the breeding grounds may also be a consequence of winter events. Dominance-mediated habitat segregation is known for redstarts wintering within the same geographic area (Marra et al. 1993; Parrish and Sherry 1994). Dominant older males displaced subordinate females and younger males to less suitable winter habitat (Marra et al. 1993; Parrish and Sherry 1994). Further, individuals in preferred habitat were in better condition at the end of the winter period and left on spring migration earlier than individuals wintering in less preferred habitat (Marra and Holberton 1998). Marra et al. (1998) provided evidence that early arriving males in New Hampshire originated from higher quality winter habitats while later arrivals were from less suitable habitats. Birds wintering on better territories arrived earlier at the breeding grounds.

Finally, differential arrival might be a result of age-dependent strategies (Mabey 2002) that result from shifting cost/benefit functions that define an individual at a particular point in its life. Individuals may have different optimal arrival times as they seek to reduce costs or increase benefits related to factors such as individual quality (Møller 1994b), age-related social 
subordinance, or inexperience. Young males may migrate later to reduce competition for resources with socially dominant older males (for a similar argument by sex, see Mabey 2002). Although early arrival is thought beneficial through providing access to high quality territories (Aebischer et al. 1996; Lozano et al. 1996; Kokko 1999), or mates (Møller 1994a; Lozano et al. 1996), costs associated with early arrival, including poor weather (Whitmore et al. 1977) and low food supplies (Nolan 1978), may be more easily offset by high quality or older, more experienced individuals (Møller 1994a, 1994b; Kokko 1999).

\section{Male arrival and territory vegetation}

Arrival timing appeared to influence territory quality for redstart males. Pattern of occupancy is commonly used to indicate territory quality (Svensson and Nilsson 1995; Aebischer et al. 1996). The first territories settled are those of the highest quality (Fretwell and Lucas 1970; Sergio and Newton 2003). In our study, early male redstarts settled on territories with younger-aged vegetation and more shrubs, suggesting a quality gradient related to vegetation age and composition. A preference for shrubby secondary growth during the breeding season is widely documented in redstarts (see Sherry and Holmes 1997 ). In fact, Hunt (1998) recently suggested that declines in redstart abundance in northeastern North America were a consequence of maturing forests and loss of early successional habitats. Anecdotal observations suggested that males at our site preferred territories with dense shrub stands possibly for the better cover afforded newly fledged offspring (R. Smith, personal observation).

\section{Arrival and reproductive performance: costs and benefits}

Relatively little information exists on the costs and benefits of early arrival by migratory birds (Møller 1994a; Brown and Brown 2000). The major costs of early arrival at our study site were probably low food abundance and increased thermoregulatory requirements resulting from cold temperatures. Over the course of the arrival period the likelihood of encountering poor weather decreased, while daily mean temperatures and overall food abundance increased (Smith 2003). The earliest arrivals faced the poorest conditions. These early individuals also carried more fat stores, which may have served as insurance against these poor conditions (Sandberg 1996; Sandberg and Moore 1996; Smith and Moore 2003). Further, redstarts arrived early during a warm, food-rich spring, a pattern consistent with the argument that birds were responding to environmental conditions.

Another potential cost incurred by females that arrive and breed early may be a reduction in probability of future breeding attempts. Nilsson (1994) demonstrated reduced survival of female blue tits (Parus caeruleus) following experimental advancement of egg-laying in the preceding year. He argued that high rates of energy expenditure associated with acquiring sufficient food to form eggs during early spring, a period of low food availability, may reduce subsequent survival. Hence, rather than experiencing maximal fitness through arriving as early as possible, females may delay arrival until environmental conditions at the breeding grounds have improved. This delay may be a factor in the commonly observed pattern in which male landbirds precede females during spring passage (Francis and Cooke 1986; Stewart et al. 2002) and arrival at the breeding grounds (Nolan 1978; Møller 1994a).

Benefits of early arrival were evident for both sexes in northern Michigan. Early individuals started breeding sooner. Seasonal declines in clutch size, along with an associated decline in the likelihood of recruitment, are well documented in passerines (Perrins 1970; Nilsson 1994; Rowe et al. 1994; van Noordwijk et al. 1995). Individual delays in the onset of breeding can have important fitness consequences, which may become evident after just a few days delay in onset of breeding (Nilsson 1994; van Noordwijk et al. 1995). As shown in this study, early nesting individuals laid more eggs, and had heavier nestlings than delayed nesters. Another commonly observed relationship, though not obvious in this study, exists between time of breeding and egg mass, with early nesters laying larger eggs (see Carey 1996). Larger clutches and heavier offspring increase the probability of offspring recruiting into the breeding population (Magrath 1991). Collectively, these male and female relationships suggest reproductive advantages in arriving early at the breeding grounds.

\section{Conservation implications}

The existence of a strong migration-breeding season linkage magnifies the importance of stopover habitat as well as the need to understand what determines en route habitat suitability. Migratory delays resulting from a migrant's inability to locate quality stopover habitat likely influence arrival timing, and the findings of this study point to fitness consequences arising from the arrival date of a bird at its breeding grounds. Unfortunately, the current state of knowledge on how transients use habitat and what habitat elements are important during migration is poor (Moore et al. 1995). Given the declines of some species of migrant landbirds (Askins et al. 1990; Askins 1995), there is an urgent need for more information about their ecology during passage (Moore et al. 1995). How well a migrant offsets en route exigencies has consequences not only for survival during migration (Moore et al. 1995), but also on subsequent reproductive performance (Smith and Moore 2003).

Acknowledgements We are grateful to members of the University of Southern Mississippi Migratory Bird Laboratory, both past and present: Jeff Buler, David Cimprich, Jeff Clark, Colleen Dwyer, Jeff Farrington, Sarah Mabey, Jen Owen, Chris Szell, Stefan Woltman and Mark Woodrey all contributed significantly to this work. The comments of David Beckett, David Ewert, Tom Sherry, Susan Walls, Wolfgang Wiltschko and two anonymous reviewers significantly improved the manuscript. This 
research was supported by the National Science Foundation, Dissertation Improvement Award (DEB-0073190), the Animal Behavior Society, Eastern Bird Banding Association, Sigma Xi, the Frank M. Chapman Memorial Student Research Fund, the Kalamazoo Audubon Society, U.S. Fish and Wildlife Service, and Barbara and Gerry Meyers. We thank Hiawatha National Forest for permission to perform this research on Forest Service property and we are grateful to The Nature Conservancy, (notable David Ewert) and Mic Hamas of Central Michigan University for logistical help. Finally, we thank our field crews for their dedicated efforts. This study complied with current laws of the USA and the State of Michigan (Federal Bird Banding Permit No. 21221, State of Michigan Bird Banding Permit No. SC 1002).

\section{References}

Aebischer A, Perrin M, Krieg M, Studer J, Meyer DR (1996) The role of territory choice, mate choice and arrival date on breeding success in the Savi's warbler Locustella luscinioides. J Avian Biol 27:143-152

Alerstam T, Lindström A (1990) Optimal bird migration: the relative importance of time, energy and safety. In: Gwinner E (ed) Bird migration: physiology and ecophysiology. Springer, Berlin Heidelberg New York, pp 331-351

Arvidsson BL, Neergaard R (1991) Mate choice in the willow warbler-a field experiment. Behav Ecol Sociobiol 29:225-229

Askins RA (1995) Hostile landscapes and the decline of migratory songbirds. Science 267:1956-1957

ChemPort

Askins RA, Lynch JF, Greenberg R (1990) Population declines in migratory birds in eastern North America. In: Power DM (ed) Current ornithology, vol 7. Plenum, New York, pp 1-57

Bensch S, Hasselquist D (1991) Territory infidelity in the polygynous great reed warbler Acrocephalus arundinaceus: the effect of variation in territory attractiveness. J Anim Ecol 60:857-871

Bensch S, Hasselquist D (1992) Evidence for active female choice in a polygynous warbler. Anim Behav 44:301-311

Berthold P (1996) Control of bird migration. Chapman and Hall, London

Brower JE, Zar JH, von Ende CN (1990) Field and laboratory methods for general ecology. Brown, Dubuque, lowa

Brown CR, Brown MB (2000) Weather-mediated natural selection on arrival time in cliff swallows (Petrochelidon pyrrhonota). Behav Ecol Sociobiol 47:339345

Brown JL (1969) Territorial behaviour and population regulation in birds. A review and re-evaluation. Wilson Bull 81:293-329

Carey C (1996) Avian energetics and nutritional ecology. Chapman and Hall, New York

Cristol DA (1995) Early arrival, initiation of nesting, and social status: an experimental study of breeding female red-winged blackbirds. Behav Ecol 6:87-93

Ellegren H (1990) Autumn migration speed in Scandinavian blue-throats Luscinia s. svecica. Ring Migr 11:121-131

Forchhammer MC, Post E, Stenseth NC (2002) North Atlantic Oscillation timing of long- and short-distance migration. J Anim Ecol 71:1002-1014

cross'ref

Francis CM, Cooke F (1986) Differential timing of spring migration in wood warblers (Parulinae). Auk 103:548-556

Fretwell SD, Lucas HJJ (1970) On territorial behavior and other factors influencing habitat distribution in birds. Acta Biotheor 19:16-36

Hagan JM, Lloyd-Evans TL, Atwood JL (1991) The relationship between latitude and the timing of spring migration of North American landbirds. Ornis Scand 22:129-136

Hasselquist D (1994) Male attractiveness, mating tactics and realized fitness in the polygynous great reed warbler. PhD Dissertation, Lund University, Lund 
Hasselquist D (1998) Polygyny in great reed warblers: a long-term study of factors contributing to male fitness. Ecology 79:2376-2390

Helms CW, Drury WHJ (1960) Winter and migratory weight and fat field studies on some North American buntings. Bird-band 31:1-40

Hochberg Y (1988) A sharper Bonferroni procedure for multiple tests of significance. Biometrika 75:800-802

Hunt PD (1998) Evidence from a landscape population model of the importance of early successional habitat to the American redstart. Conserv Biol 12:1377-1389

cross ${ }^{\text {ref }}$

James FC, Shugart HHJ (1970) A quantitative method of habitat description. Audobon Field Notes 24:727-736

Kokko H (1999) Competition for early arrival in migratory birds. J Anim Ecol 68:940-950

cross ${ }^{\text {ref }}$

Krementz DG, Pendleton GW (1990) Fat scoring: sources of variability. Condor 92:500-507

Landmann A, Kollinsky C (1995) Age and plumage related territory differences in male black redstarts: the (non)-adaptive significance of delayed plumage maturation. Ethol Ecol Evol 7:147-167

Langefors Å, Hasselquist D, van Schantz T (1998) Extra-pair fertilizations in the sedge warbler. J Avian Biol 29:134-144

Lozano GA, Perreault S, Lemon RE (1996) Age, arrival date and reproductive success of male American redstarts Setophaga ruticilla. J Avian Biol 27:164-170

Mabey SE (2002) Sex-based differential migration: An examination of proximate causes and ecological consequences. PhD Dissertation, University of Southern Mississippi, Hattiesburg

Magrath RD (1991) Nestling weight and juvenile survival in the blackbird, Turdus merula. J Anim Ecol 60:335-351

Magrath RD (1992) The effect of egg mass on the growth and survival of blackbirds: a field experiment. J Zool 227:639-653

Marra P, P., Holberton RL (1998) Corticosterone levels as indicators of habitat quality: effects of habitat segregation in a migratory bird during the non-breeding season. Oecologia 116:284-292.

[SpringerLink]

Marra PP, Sherry TW, Holmes RT (1993) Territorial exclusion by a long-distance migrant warbler in Jamaica: a removal experiment with American redstarts (Setophaga ruticilla). Auk 110:565-572

Marra PP, Hobson KA, Holmes RT (1998) Stable-carbon isotopes link winter and summer events in a migratory bird. Science 282:18841886

\begin{tabular}{|l|l|l|l}
\hline cross & ChemPort & PubMed \\
\hline
\end{tabular}

Martin TE (1987) Food as a limit on breeding birds: a life history perspective. Annu Rev Ecol Syst 18:453-487

cross ${ }^{\text {ref }}$

Møller AP (1994a) Phenotype-dependent arrival time and its consequences in a migratory bird. Behav Ecol Sociobiol 35:115-122 [SpringerLink]

Møller AP (1994b) Sexual selection and the barn swallow. Oxford University Press, Oxford

Moore FR, Gauthreaux SAJ, Kerlinger P, Simons TR (1995) Habitat requirements during migration: important link in conservation. In: Martin TE, Finch DM (eds) Ecology and management of neotropical migratory birds. Oxford University Press, New York, pp 121-144

Moore FR, Mabey S, Woodrey M (2003) Priority access to food in migratory birds: age, sex and motivational asymmetries. In: Berthold P, Gwinner E, Sonnenschein E (eds) Avian migration. Springer, Berlin Heidelberg New York, pp 281-292

Nilsson J-Å (1994) Energetic bottle-necks during breeding and the reproductive cost of being too early. J Anim Ecol 63:200-208

Nolan VJ (1978) Ecology and behavior of the prairie warbler, Dendroica discolor, vol 26. American Ornithologists' Union, Washington, D.C. 
Noordwijk AJ van, McCleery RH, Perrins CM (1995) Selection for the timing of great tit breeding in relation to caterpillar growth and temperature. J Anim Ecol 64:451-458

Parrish JD, Sherry TW (1994) Sexual habitat segregation by American redstarts wintering in Jamaica: importance of resource seasonality. Auk 111:38-49

Pärt T (2001) The effects of territory quality on age-dependent reproductive performance in the northern wheatear, Oenanthe oenanthe. Anim Behav 62:379-388

cross ${ }^{\text {ref }}$

Perrins CM (1970) The timing of birds' breeding seasons. Ibis 112:242-255

Perrins CM, McCleery RH (1989) Laying dates and clutch size in the great tit. Wilson Bull 101:236-253

Pyle P (1997) Identification guide to North American birds. Slate Creek Press, Bolinas, Calif.

Rowe L, Ludwig D, Schluter D (1994) Time, condition, and the seasonal decline of avian clutch size. Am Nat 143:698-722 cross ${ }^{\text {ref }}$

Saether B-E (1990) Age-specific variation in reproductive performance of birds. In: Power DM (ed) Current ornithology, vol 7. Plenum, New York, pp 251-283

Sandberg R (1996) Fat reserves of migrating passerines at arrival on the breeding grounds in Swedish Lapland. Ibis 138:514-524

Sandberg R, Moore FR (1996) Fat stores and arrival on the breeding grounds:reproductive consequences for passerine migrants. Oikos 77:577-581

Sergio F, Newton I (2003) Occupancy as a measure of territory quality. J Anim Ecol 72:857-865

cross ${ }^{\text {ref }}$

Sherry TW, Holmes RT (1997) American redstart (Setophaga ruticilla). In: Poole A, Gill F (eds) The birds of North America, no. 277. Th Birds of North America, Philadelphia, Pa.

Smith HG, Bruun M (1998) The effect of egg size and habitat on starling nestling growth and survival. Oecologia 115:59-63 [SpringerLink]

Smith RJ (2003) Resources and arrival of landbird migrants at their northerly breeding grounds: linking en route with breeding season events. PhD Dissertation, University of Southern Mississippi, Hattiesburg

Smith RJ, Moore FR (2003) Arrival fat and reproductive performance in a long-distance passerine migrant. Oecologia 134:325-331 PubMed

SPSS (1999) SPSS for Windows. SPSS, Chicago

Stewart RLM, Francis CM, Massey C (2002) Age-related differential timing of spring migration within sexes in Passerines. Wilson Bull 114:264-271

Svensson E, Nilsson J-A (1995) Food supply, territory quality, and reproductive timing in the blue tit (Parus caeruleus). Ecology 76:18041812

Whitmore RC, Mosher JA, Frost HH (1977) Spring migrant mortality during unseasonable weather. Auk 94:778-781

Widmer M, Biebach $\mathrm{H}$ (2001) Changes in body condition from spring migration to reproduction in the garden warbler Sylvia borin: a comparison of a lowland and a mountain population. Ardea 89:57-68

Wilkinson L (1998) SYSTAT. SPSS, Chicago

Wolfenbarger LL (1999) Red coloration of male northern cardinals correlates with mate quality and territory quality. Behav Ecol 10:80-90 cross ${ }^{\text {ref }}$

Woodrey MS (1995) Stopover behavior and age-specific ecology of neotropical passerine migrant landbirds during autumn along the 
northern coast of the Gulf of Mexico. PhD Dissertation, University of Southern Mississippi, Hattiesburg

Woodrey MS, Moore FR (1997) Age-related differences in the stopover of fall landbird migrants on the coast of Alabama. Auk 114:695-707

Yong W, Moore FR (1994) Flight morphology, energetic condition, and the stopover biology of migrating thrushes. Auk 111:683-692

Yong W, Finch DM, Moore FR, Kelley JF (1998) Stopover ecology and habitat use of migratory Wilson's warblers. Auk 115:829-842

Zar JH (1996) Biostatistical analysis. Prentice-Hall, Englewood Cliffs, N.J.

http://www.springerlink.com/media/A5T5AD3KWJ6RQGF9KYB0/Contributions/H/7/E/U/H7EUKGM8YDAX3DL2_h... 10/25/2004 